\title{
Spinal hemangioblastoma arising from cervical nerve root
}

Jiuhong Li, MD, * Jiaojiang He, MD,* Susu Lu, MD, Xuhui Hui, PhD, and Haifeng Chen, MD

Neurology ${ }^{\circledR}$ 2020;95:791-792. doi:10.1212/WNL.0000000000010836

Figure $1 \mathrm{MRI}$ findings
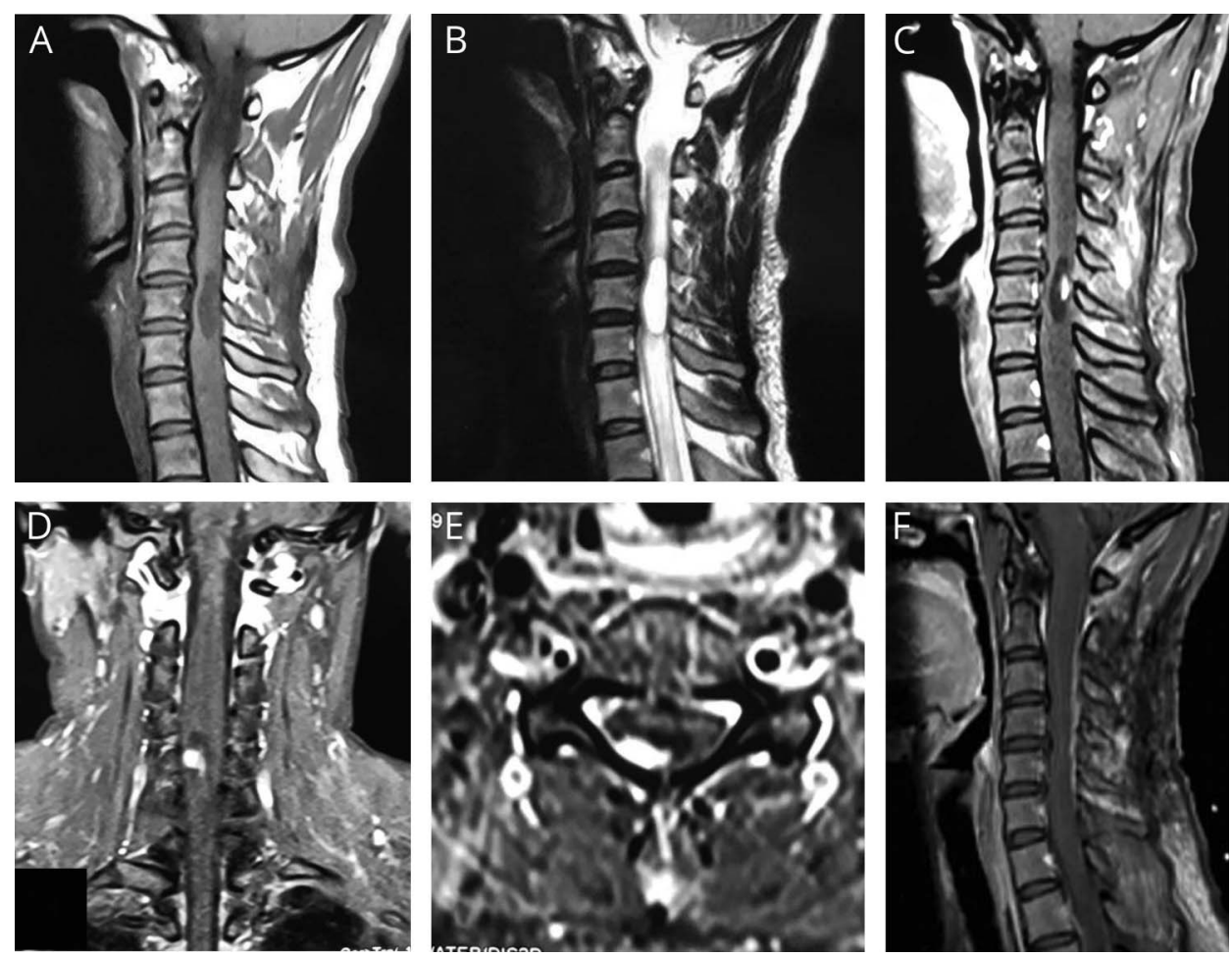

Preoperative imaging revealed a hypointensity mass in sagittal T1 (A) and hyperintensity in T2-weighted imaging (B). The lesion was cystic-solid in sagittal (C) and coronal (D) imaging after administration of gadolinium and axial enhanced MRI (E) showed it was extramedullary. Postoperative contrast-enhanced MRI (F) depicted the tumor was totally resected.

A 39-year-old woman presented with neck and shoulder pain for 3 months. The MRI scan revealed a cystic-solid lesion located at C5 (figure 1, A-E). The patient received an operation and a small blood blister-like soft mass was detected. The tumor originated from proximal cervical nerve root and compressed the spinal medulla (figure 2, A-C). Pathologic diagnosis was hemangioblastoma (figure 2D). Postoperative gadolinium-enhanced MRI showed a gross total resection of the tumor (figure $1 \mathrm{~F}$ ). Spinal hemangioblastomas frequently originate from the medulla, ${ }^{1}$ and nerve root originated hemangioblastoma is scarce. Our case provides a directviewing description and pathologic confirmation of a new subset of classification for origin of spinal hemangioblastomas.

\author{
Correspondence \\ Dr. Chen \\ chenhaifengwc@163.com
}



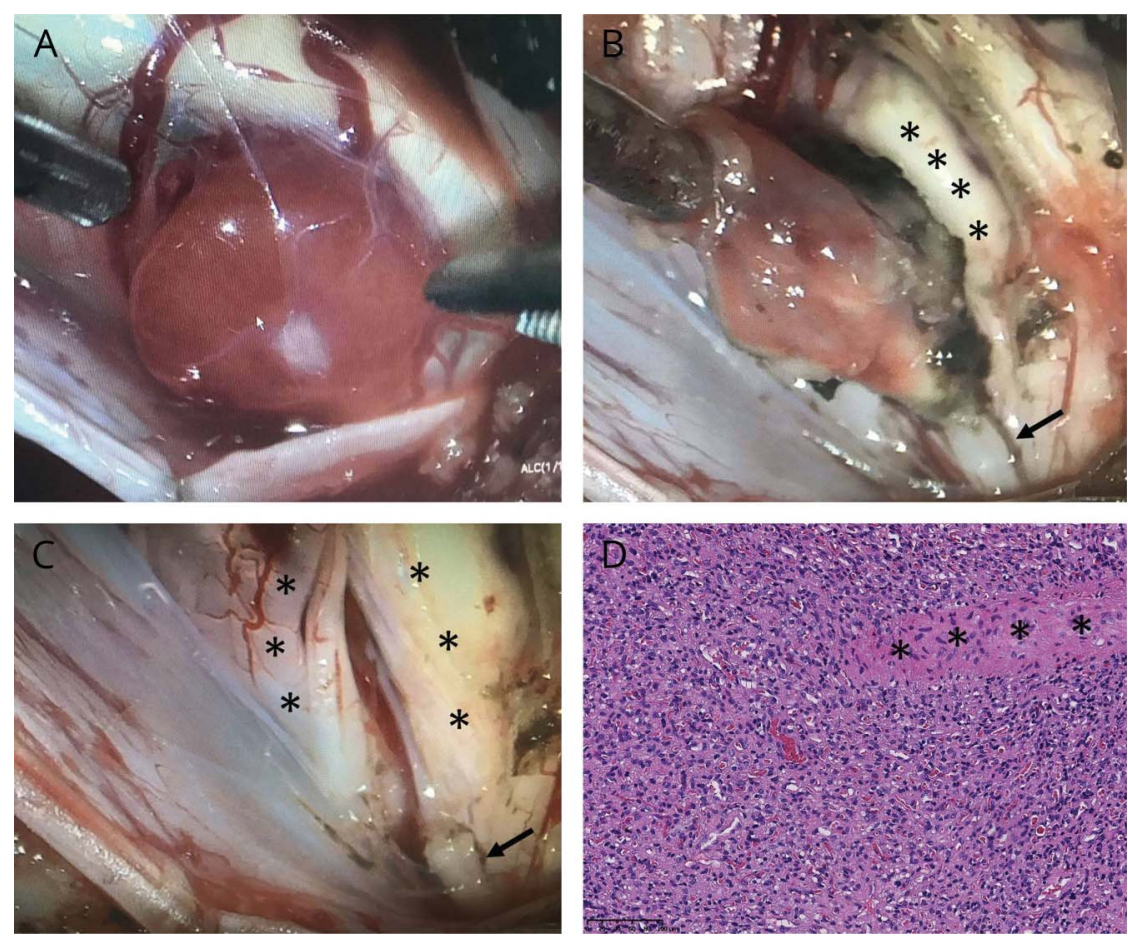

During operation, a soft blood blister-like mass was detected (A). After carefully dissecting it, we found that the lesion arose from the proximal cervical nerve root (arrow), compressing the spinal medulla (asterisks) (B). The tumor was totally resected so that the nerve root (arrow) and spinal medulla (asterisks) were revealed (C). Hematoxylin \& eosin (magnification, $\times 200$ ) (D) showed large intratumoral vascular channels, loose stromal elements, and prominent capillaries characteristic of a hemangioblastoma; the nerve root tissue (asterisks) is surrounded by tumor stroma.

\section{Study funding}

No targeted funding reported.

\section{Disclosure}

The authors report no disclosures relevant to the manuscript. Go to Neurology.org/N for full disclosures.

\section{Appendix Authors}

\begin{tabular}{lll}
\hline Name & Location & Contribution \\
\hline $\begin{array}{l}\text { Jiuhong } \\
\text { Li }\end{array}$ & $\begin{array}{l}\text { Chengdu, } \\
\text { Sichuan, } \\
\text { China }\end{array}$ & $\begin{array}{l}\text { Study design, data collection and analysis, } \\
\text { drafting the manuscript, analysis and } \\
\text { interpretation of data }\end{array}$ \\
$\begin{array}{l}\text { Jiaojiang } \\
\text { He }\end{array}$ & $\begin{array}{l}\text { Chengdu, } \\
\text { Sichuan, } \\
\text { China }\end{array}$ & $\begin{array}{l}\text { Data collection, drafting the manuscript, } \\
\text { revising the manuscript }\end{array}$ \\
\hline
\end{tabular}

Appendix (continued)

\begin{tabular}{lll}
\hline Name & Location & Contribution \\
\hline Susu Lu & $\begin{array}{l}\text { Chengdu, } \\
\text { Sichuan, } \\
\text { China }\end{array}$ & $\begin{array}{l}\text { Acquisition of data, analysis and } \\
\text { interpretation of data, drafting the } \\
\text { manuscript }\end{array}$ \\
\hline $\begin{array}{l}\text { Xuhui } \\
\text { Hui }\end{array}$ & $\begin{array}{l}\text { Chengdu, } \\
\text { Sichuan, } \\
\text { China }\end{array}$ & $\begin{array}{l}\text { Study concept and design, study } \\
\text { supervision, revising the manuscript }\end{array}$ \\
\hline $\begin{array}{l}\text { Haifeng } \\
\text { Chen }\end{array}$ & $\begin{array}{l}\text { Chengdu, } \\
\text { Sichuan, } \\
\text { China }\end{array}$ & $\begin{array}{l}\text { In charge of surgery, study concept and } \\
\text { design, clinical care and investigative } \\
\text { workup of the patient }\end{array}$ \\
&
\end{tabular}

\section{Reference}

1. Westwick HJ, Giguere JF, Shamji MF. Incidence and prognosis of spinal hemangioblastoma: a surveillance epidemiology and end results study. Neuroepidemiology 2016;46:14-23. 


\section{Neurology}

\section{Spinal hemangioblastoma arising from cervical nerve root Jiuhong Li, Jiaojiang $\mathrm{He}$, Susu Lu, et al.}

Neurology 2020;95;791-792 Published Online before print September 15, 2020 DOI 10.1212/WNL.0000000000010836

This information is current as of September 15, 2020

Updated Information \& Services

References

Subspecialty Collections

Permissions \& Licensing

Reprints including high resolution figures, can be found at: http://n.neurology.org/content/95/17/791.full

This article cites 1 articles, 0 of which you can access for free at: http://n.neurology.org/content/95/17/791.full\#ref-list-1

This article, along with others on similar topics, appears in the following collection(s):

\section{All Education}

http://n.neurology.org/cgi/collection/all_education

All Spinal Cord

http://n.neurology.org/cgi/collection/all_spinal_cord

MRI

http://n.neurology.org/cgi/collection/mri

Nerve tumor

http://n.neurology.org/cgi/collection/nerve_tumor

Spinal cord tumor

http://n.neurology.org/cgi/collection/spinal_cord_tumor

Information about reproducing this article in parts (figures,tables) or in its entirety can be found online at:

http://www.neurology.org/about/about_the_journal\#permissions

Information about ordering reprints can be found online:

http://n.neurology.org/subscribers/advertise

Neurology ${ }^{\circledR}$ is the official journal of the American Academy of Neurology. Published continuously since 1951, it is now a weekly with 48 issues per year. Copyright (O) 2020 American Academy of Neurology. All rights reserved. Print ISSN: 0028-3878. Online ISSN: 1526-632X.

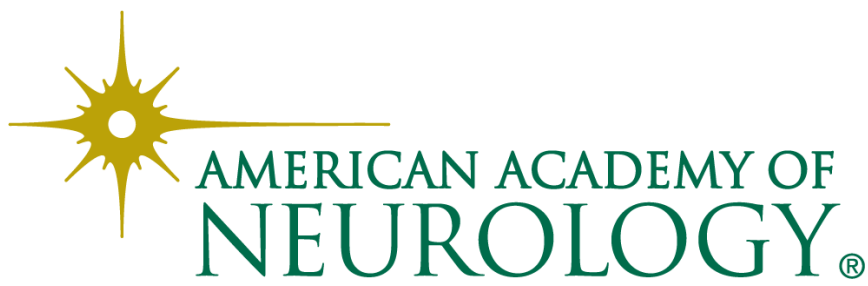

